\section{Nasal Cancer in the Shoe Industry}

SIR,-In our article on "Nasal Cancer in the Northamptonshire Boot and Shoe Industry" (14 February, p. 385) we were unable to give estimates of incidence within the industry because we lacked comprehensive information on the numbers of men employed in the different departments. We have since received from the British Footwear Manufacturers' Federation national figures relating to 1949-61 inclusive giving the numbers of operatives in each sex employed in the various departments. The figures include the numbers of men and women employed in clicking, closing, pressing, lasting, finishing, and shoe room departments. In making the calculations in the Table the figures for 1949-61 have been averaged and the proportions applied to the Northamptonshire industry. If the cases of for all types of tumour is $\mathbf{0 . 0 1}$ per thousand per annum, a rate closely similar to that experienced by all males over 15 years of age in southern England.

The figures from the British Footwear Manufacturers' Federation show that less than $5 \%$ of women employed in the boot and shoe industry work in the press and finishing rooms. This explains the very low incidence of nasal cancer in women in the Northamptonshire footwear industry. To date we have information about only two women with nasal cancer in the footwear industry. One had worked for three years sanding heels and is presumably therefore one of the small minority of women who worked in the finishing department. The other worked for seven years in the closing rooms of a shoe factory.

\begin{tabular}{|c|c|c|c|c|c|c|c|c|c|}
\hline \multirow{2}{*}{\multicolumn{3}{|c|}{ Department }} & \multirow{2}{*}{ Population } & \multicolumn{2}{|c|}{ Adenocarcinoma } & \multicolumn{2}{|c|}{ Other Carcinomas } & \multicolumn{2}{|c|}{ All Carcinomas } \\
\hline & & & & No. & Incidence* & No. & Incidence* & No. & Incidence* \\
\hline $\begin{array}{l}\text { Press and fir } \\
\text { Other depts. } \\
\text { Unclassified }\end{array}$ & $\begin{array}{l}\text { ing } \\
\ldots \\
\ldots\end{array}$ & $\begin{array}{l}\text { ms } \\
\ldots \\
\cdots\end{array}$ & $\begin{array}{r}5,000 \\
10,660 \\
-\end{array}$ & $\frac{7}{2}$ & $\begin{array}{c}0.07 \\
- \\
-\end{array}$ & $\begin{array}{l}7 \\
2 \\
2\end{array}$ & $\begin{array}{c}0.07 \\
- \\
-\end{array}$ & $\begin{array}{r}14 \\
2 \\
4\end{array}$ & $\begin{array}{c}0.14 \\
0.01 \\
-\end{array}$ \\
\hline Total & .. & .. & 15,660 & 9 & 0.03 & 11 & 0.04 & 20 & 0.06 \\
\hline
\end{tabular}

*Average annual incidence per thousand.

nasal cancer in males known to have occurred during the twenty year period 1950-69 are related to these populations we find that the risk is virtually limited to persons working in the press and finishing departments. The average incidence rate per annum for all types of tumour of the nasal cavity and sinuses in men working in the press and finishing departments is 0.14 per thousand: adenocarcinoma 0.07 per thousand; for other types of nasal tumour 0.07 per thousand. For males working in other departments of the industry the risk

\section{Breathlessness and Anxiety}

SIR,-Dr. N. C. Oswald and his colleagues (4 April, p. 14) suggest that there may be a case for greater use of ratings of neuroticism and anxiety in patients with bronchitis and asthma to help in management.

Another practical use to which such psychological tests could be put is as an aid in diagnosis. This was demonstrated by a study I carried out at the Myasthenia Gravis Clinic, Massachusetts General Hospital, Boston. The main purpose of the investigation was to determine if a simple questionary test of neuroticism could be of use in detecting those patients presenting with weakness and fatigue of psychological origin. Schwab and Perlo, ${ }^{1}$ in a study of

\begin{tabular}{l|r|r} 
& Mean & S.D \\
M.P.I. manual norms & $20 \cdot 6$ & $10 \cdot 6$ \\
Normal controls & $18 \cdot 8$ & $5 \cdot 2$ \\
Neurotic controls & 34.6 & 10.0 \\
Short duration myasthenics & $19 \cdot 1$ & 5.3 \\
Chronic fatigue syndromes & 38.6 & 9.3
\end{tabular}

syndromes simulating myasthenia gravis, found that in $37.6 \%$ of the patients examined the symptoms were of emotional aetiology and were placed in the category of chronic fatigue syndrome. The Maudsley Personality Inventory (M.P.I. $)^{2}$ was given to
This additional information confirms that the risk of nasal cancer in the footwear industry is concentrated among the comparatively small number of persons engaged in dusty jobs. In this small group, almost all of whom are men, the risk approximates to that of carcinoma of the rectum.-We are, etc.,

\section{E. D. Acheson. \\ R. H. COWDELL.}

B. Jolles.

The University,
Southampton.

30 patients with this syndrome and also to controls matched for age, sex, and colour consisting of groups of 30 normals, neurotics, and myasthenic patients (duration less than two years). The neuroticism scores in the various groups are summarized in the Table. Those patients diagnosed as having a chronic fatigue syndrome scored significantly higher on the neurotic scale of the M.P.I. than did the normal controls ( $t$-test, $p<0.001)$. There was no definite cut-off point, but a score above 30 was suspect and should suggest further psychiatric assessment.

The neurotic patient, with and without organic illness, is a frequently met problem in the general hospital, particularly in certain clinics. ${ }^{3}$ It may be that there is a place for the wider use of short, self-administered personality questionaries to help detect the psychoneurotic subject.-I am, etc.

\section{H. BRIAN MCNAMEe.}

Department of Psychiatry

Queen's University

Kingston, Ontario, Canad.

REFERENCES

Schwab, R. S., and Perlo, V. P., Annals of the New York Academy of Sciences, 1966, 135, 350 .

Eysenck, H. J., The Manual of the Maudsley Personality Inventory. Educational and Industrial Testing Service, California, 1962 Davies, B., Postgraduate Medical fournal, 1964.

\section{Neurological Complications of Infective Endocarditis}

SIR,-Your leading article (13 June, p. 619) on neurological complications of infective endocarditis omits to draw attention to cerebral abscess, which is one important and urgently remediable complication of this condition. Unfortunately, cerebral abscess may present as a neurological deficit of sudden onset, and in these circumstances it is dangerously easy to ascribe this mistakenly to an embolic or haemorrhagic incident. Physicians should be aware of this difficulty in diagnosis, and that it is now a wise measure to perform a radioactive brain scan on any patient with bacterial endocarditis who develops a focal neurological deficit or deterioration in the level of consciousness.-I am, etc.,

JOHN GARFIELD.

Wessex Neurological Centre, Southampton General Hospital, Southampton, Hants.

\section{Soya Milk}

SIR,-Your account of the appeal of the Secretary of State to referees in the case of the doctor who prescribed Soya Milk for milk allergy (Supplement, 16 May, p. 128) and the referees' decision that Soya Milk was not a drug which the executive council was bound to provide, is difficult to understand. The Standing Joint Committee on the Classification of Proprietary Preparations in the Report on the Definition of Drugs (Borderline Substances) gave a list of preparations which might be regarded as drugs and prescribed on E.C. 10 in the treatment of specified illnesses. The list of "Borderline Substances" is brought up to date in each issue of the Standing Joint Committee's Proplist. A soya-based milk substituteVelactin (A. Wander Ltd.)-has been included in the list since its first publication. The "conditions in which it would be regarded as a drug" were originally given as "milk intolerance; lactose without sucrose intolerance." In Proplist for February, 1970, this is revised to "All forms of milk intolerance." Doesn't Soya Milk mean a soya-based milk substitute? Is milk allergy not included in all forms of milk intolerance?-I am, etc.,

\section{T. P. EDDY.}

$$
\begin{gathered}
\text { Department of Human Nutrition, } \\
\text { London School of Hygiene } \\
\text { and Tropical Medicine, } \\
\text { London W.C.1. }
\end{gathered}
$$

\section{Child-resistant Containers}

SIR, - The incidence of acute poisoning of children in Britain is rising rapidly and remorselessly. The most promising recent advance in the prevention of paediatric poisoning is the development in North America of the child-resistant medicine container. $^{1-5}$ Following the introduction of such containers poisoning from drugs has been reduced by as much as $90 \%$; other poisonings-mainly from household productshave decreased by as much as $40 \% .^{25}$ The success of child-resistant containers is in contrast to the failure of conventional forms of poison control directed towards improved 